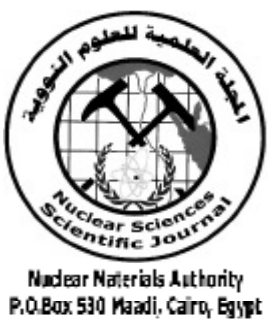

ISSN 2314-5609

Nuclear Sciences Scientific Journal

vol. 3 , p $15-25$

2014

\title{
GRANITES OF GABAL EL-DOB AREA AND ASSOCIATED PEGMATITES, CENTRAL EASTERN DESERT, EGYPT: GEOCHEMISTRY AND SPECTROMETRY
}

\author{
FARRAGE M. KHALEAL \\ Nuclear Materials Authority
}

\begin{abstract}
The late Pan-African El-Dob granites in the Egyptian Central Eastern Desert are small and circular bodies from older and younger granites. The older granitoids are represented by granodiorites and tonalites and they are intruded by the younger gabbros and younger granites with sharp contacts. The younger granites are represented by alkali feldspar granites cropping out in the central part of the studied area forming Gable El-Dob. The older and younger granites are cut by pegmatite and quartz veins. El-Dob granites are peraluminous and I-type granites. The older granites belong to volcanic arc granites (VAG), while the younger granites belong to within plate granites (WPG). Pegmatite veins possess high contents of important elements as $\mathrm{Zn}, \mathrm{Y}$ and $\mathrm{Cu}$. The El-Dob granites have relatively high uranium and thorium contents. The average equivalent uranium is $19.2 \mathrm{ppm}$ for the older granites and $32.5 \mathrm{ppm}$ for the younger granites, the average $\mathrm{eTh}$ is $55.4 \mathrm{ppm}$ with the average $\mathrm{eTh} / \mathrm{eU}=3.1$ for the older granites and the average $\mathrm{eTh}$ is $86 \mathrm{ppm}$ with the average $\mathrm{eTh} / \mathrm{eU}=2.8$ for the younger granites. These radiometric measurements are higher than the Clark values, i. e uraniferous granites. In pegmatites, the average eU content is 32.5 $\mathrm{ppm}$ and the average of eTh content is $86 \mathrm{ppm}$. Most of the radioactive anomalies are associated with the pegmatites.
\end{abstract}

\section{INTRODUCTION}

Granitoids constitute an important rock group that covers vast areas of the AraboNubian shield. They cover about $38 \%$ of the basement outcropping in Egypt. In the Eastern Desert of Egypt, granitoid rocks constitute about $61 \%$ of the total basement complex terrain (Stern et al., 1984). The Eastern Desert of Egypt has been described as one of the most intensively dyke-intruded and granitoids pluton-pierced segments of the continental crust (Vail, 1986; Bentor, 1985). The small epizonal late Pan-African alkali feldspar granites to monzogranite plutons of the Eastern Desert range in $\mathrm{Rb}-\mathrm{Sr}$ age from 620 to $570 \mathrm{Ma}$ (Hassan and Hashad, 1990).
The Egyptian granitoids attracted the attention of many workers who classified them according to several ways as: ${ }^{(1)}$ Type localities (Shaitian and Gattarian granites), (2) Relative age (older and younger granitoids), ${ }^{(3)}$ Dominant colour (grey, red and pink) or ${ }^{(4)}$ Their relation to orogeny (syn-, late- and post-orogenic granites).

The granitoid rocks are differentiated into authochthonous, per-authochthonous and intrusive varieties as well as porphyritic adamellite, red granites and later alkaline granites (Sabet et al., 1972b). The anomalous radioactivity at Wadi Abu Zawal is compared to altered pink granites and pegmatites (El Tahir, 1978). Abu El Hassan (1995) mentioned that 
the area around Gable El-Dob is covered by Dokhan volcanics, younger gabbros, syenogranites and grey granites and post-granite dykes. On the other hand, Tungsten ores were discovered in 1930 in Wadi El-Dob. Tin-deposits in El-Dob area belong to the high temperature hydrothermal vein deposits of quartzCassieterite and quartz-wolframite type (El Shazly, 1957 and Akaad and El Ramly 1960). This paper investigates the geology, geochemistry and spectrometry of El-Dob granites and associated pegmatites.

\section{GEOLOGIC SETTING}

The studied area covers about $700 \mathrm{~km}^{2}$ of the crystalline Pan African basement rocks and lies between lat. 26 40' and $26^{\circ} 50^{\prime} \mathrm{N}$ and long. $33^{\circ} 19^{\prime}$ and $33^{\circ} 30^{\prime} \mathrm{E}$ (Fig. 1). The basement rocks, of late Proterozoic age, cropping out in the area are classified into: (1) Older granitoids (oldest), (2) Dokhan Volcanics, (3) younger gabbros, (4) Younger granites, and (5) Acidic and basic dykes (youngest). The micro-fractures of these rocks are sometimes filled with quartz and feldspar veinlets.

\section{Older Granitoids (Granodiorites- Tonalites)}

They represent the dominant type in the area under investigation covering a total area of about $75 \%$. It is intruded by the younger gabbros and younger granites with sharp contacts. Generally, the older granites are medium to coarse grained and locally possess foliation particularly along their eastern margin. They are characterized by low relief, spheroidal and cavernous weathering. They are distinguished into tonalites and granodiorites that grade imperceptibly into each other (Asran et al., 2001). The mineralized quartz veins are found in association with a variety of older granites that the quartz-casseterite-wolframite veins are confined only to the margins of the granite masses and the adjacent parts of the country rocks (El Shazly, 1957; Hassan et al., 1984; Takla and Nowier, 1980). Dokhan volcanics occupy moderate to high relief terrains in the northwestern and southwestern parts of the mapped area. They comprise andesites, porphyritic rhyodacites and rhyolites. Younger gabbros crop out along Wadi Abu Zawal as

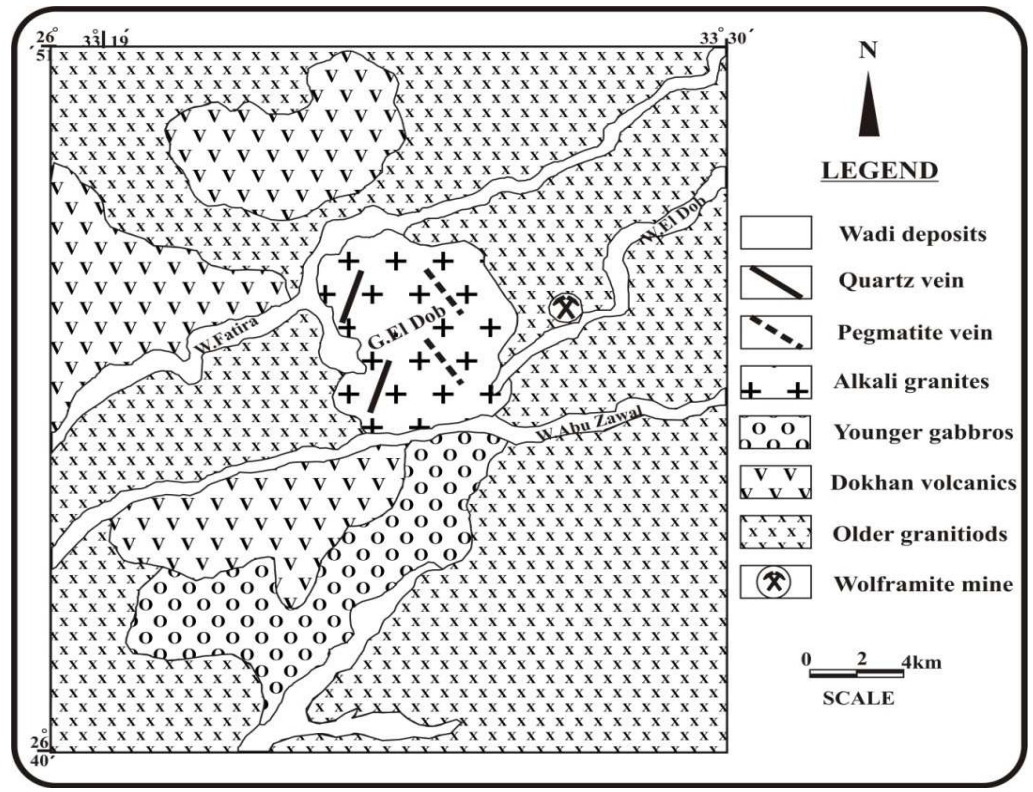

Fig. 1: Geologic map of Gabal El Dob area 
homogeneous pockets. They form terrains of low to moderate relief. They are intruded into the older granites and in turn intruded by the younger granites. Younger granites are represented by alkali feldspar granites, which crop out in the central part of the studied area. They represent the last phase of the younger granites forming El-Dob. They are characterized by yellowish pink color and high relief forming small plates with oval to circular outlines intruding the older granites. Younger granites are cut by micro-pegmatitic feldspathic and quartz veins. Pegmatites hosting copper, lead, and zinc minerals occur close to the marginal zone of G. El-Dob. These minerals are almost found confined to the feldspar envelopes close to their boundary with the quartz core or closely associated with mica aggregates. Pegmatites are of variable size and their trend being almost parallel to the contact zone (Fig. 2). Dimensions up to $400 \mathrm{~m}$ long and $10 \mathrm{~m}$ width are recorded. All these pegmatites are of granitic composition and characterized by compositional heterogeneity and zoning. Pegmatites are formed of an outer zone of blocky feldspars with subordinate biotite clusters that envelope an inner core of massive quartz; which occasionally exists as disconnected pods.

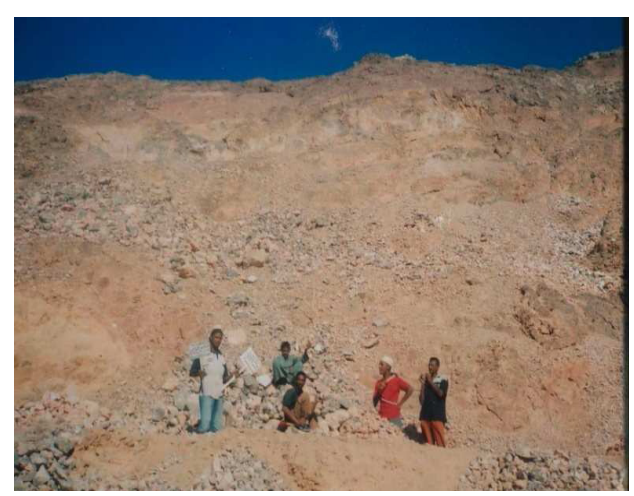

Fig. 2: A field photograph showing pegmatite at Gabal El-Dob

\section{PETROGRAPHY}

\section{The Older Granitoids (Granodiorites- Tonalites)}

The older granitoids are coarse to medium grained and composed mainly of plagioclase, alkali feldspar, hornblende, biotite and quartz. Titanite and opaques are common as accessory minerals, while sericite, chlorite and epidote are secondary mineral constituents. Plagioclase occurs as subhedral to anhedral albite crystals with deformation lamellae showing varied degrees of alteration to sericite, where the alteration effect is restricted to the core giving rise to some sort of zoning. Sometimes, plagioclase shows corrosional boundaries against hornblende and biotite, while biotite and hornblende sheets wrapped the crystals of plagioclase. Alkali feldspars may be either orthoclase or microcline. Both are colorless and may appear dusty due to alteration. Hornblende occurs as anhedral to subhedral crystals partially altered to chlorite. Biotite is present in fair amounts and occurs as flaky with brown colors. Quartz appears featureless in plane light due to its low relief, lack of cleavage and immunity to alteration. Titanite and opaques occur in remarkably large crystals. Titanite is of wedge-shaped or "flattened diamond" shape and euhedral grains.

\section{The Younger Granites (Alkali Feldspar Granites)}

They are commonly coarse-grained, hypidiomorphic to allotriomorphic. They are composed of microcline microperthite, quartz, plagioclase and biotite. Muscovite and chlorite are secondary minerals. Apatite, fluorite, zircon, allanite and monazite are accessory minerals. Microcline microperthite is a uniform, lenticular as well as patchy pattern. Plagioclase occurs as anhedral to subhedral crystals. Biotite flakes enclaves zircon crystals showing pleochoic halos due to radiogenic effect of zircon inclusions. 


\section{GEOCHEMISTRY}

\section{Analytical Methods}

Fifteen samples of the studied El-Dob granitic rocks (eight samples of the older granites and seven samples of the younger granites) were chemically analyzed in the Nuclear Materials Authority (NMA). Also, trace elements were determined for six samples of the pegmatites. Major oxides and trace elements (Tables 1 and 2) were determined by the wet method and $\mathrm{XRF}$ technique, respectively.

By applying the multicationic scheme of De la Roche et al. (1980) and $\mathrm{SiO}_{2}$ vs. $\mathrm{Na}_{2} \mathrm{O}+\mathrm{K}_{2} \mathrm{O}$ binary diagram of Middlemost (1985) (Figs. $3 \& 4)$. It is showed that the first pluton ranges from granodiorite to tonalite fields and the other is lie in alkali feldspar granite fields.

\section{Geochemical Characteristics}

El-Dob younger granites are relatively rich in $\mathrm{SiO}_{2}, \mathrm{~K}_{2} \mathrm{O}$ and $\mathrm{Na}_{2} \mathrm{O}$ contents but low in $\mathrm{CaO}, \mathrm{TiO}_{2}, \mathrm{Fe}_{2} \mathrm{O}_{3}, \mathrm{Al}_{2} \mathrm{O}_{3}, \mathrm{MgO}, \mathrm{MnO}$ and $\mathrm{P}_{2} \mathrm{O}_{5}$ than the older granites (Table 1). This reflects the high alkali feldspar contents and lack of ferromagnesian minerals in younger granites.

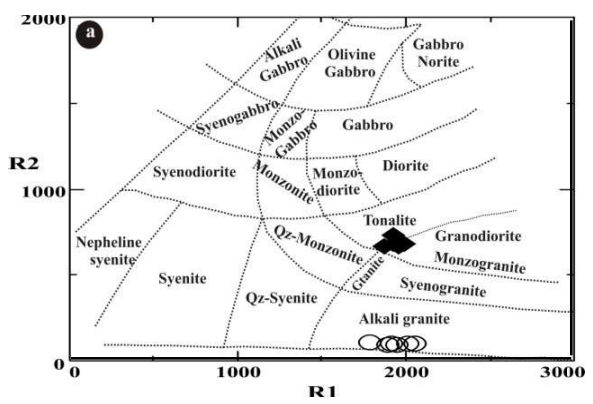

Fig.3: Multicationic plot of geochemical data for the El-Dob granites according to De la Roche et al. $(1980), \mathrm{R} 1=4 \mathrm{Si}-11(\mathrm{Na}+\mathrm{K})-2(\mathrm{Fe}+\mathrm{Ti}) ; \mathrm{R} 2$ $=6 \mathrm{Ca}+2 \mathrm{Mg}+\mathrm{Al}$

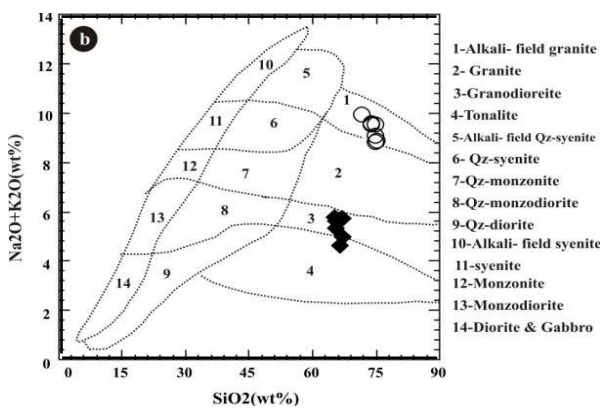

Fig.4: $\mathrm{SiO}_{2}$ vs. $\mathrm{Na}_{2} \mathrm{O}+\mathrm{K}_{2} \mathrm{O}$ binary diagram according to Middlemost, 1985 , Older granites Younger granites

Table 1: Major oxides (wt\%)and trace elements ( $\mathrm{ppm})$ analysis of El-Dob granitic rocks, Central Eastern Desert

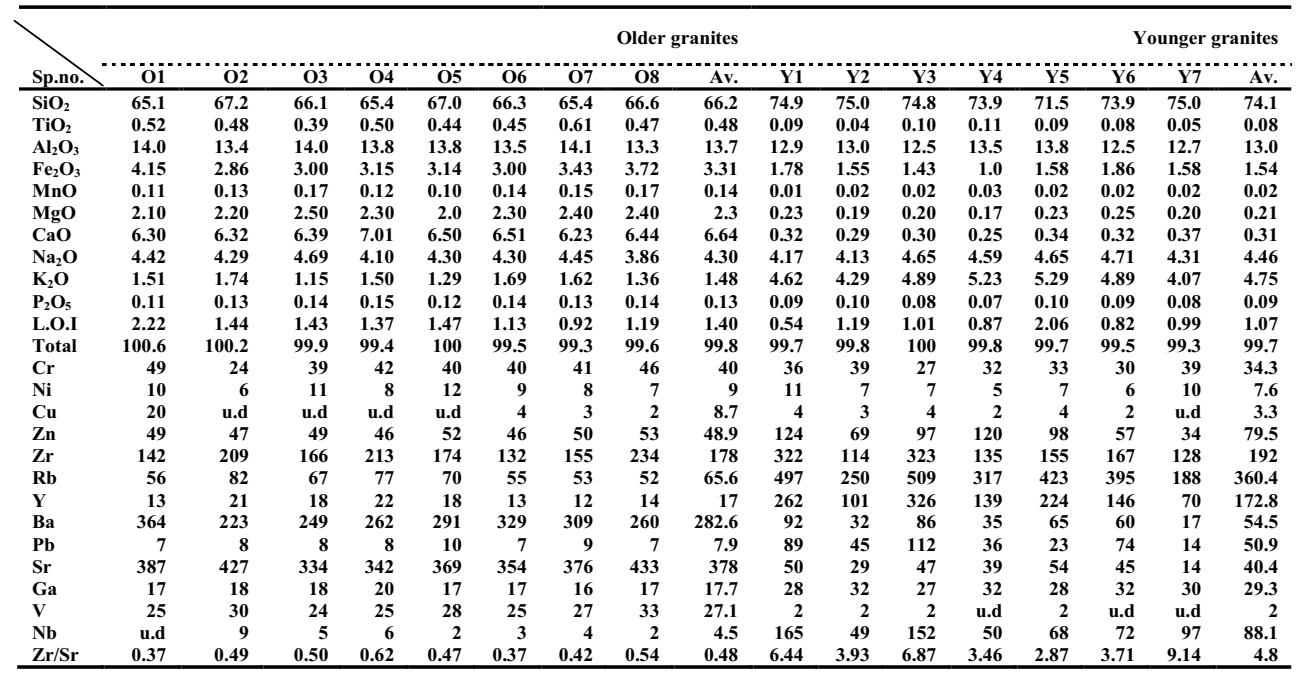


Table 2: Trace elements analysis of the pegmatite-bearing gold and platinum at El-Dob granitic area, Central Eastern Desert

\begin{tabular}{|c|c|c|c|c|c|c|c|c|c|c|c|c|c|c|c|c|}
\hline & $\mathrm{Cr}$ & $\mathrm{Ni}$ & $\mathrm{Cu}$ & $\mathrm{Zn}$ & $\mathrm{Zr}$ & $\mathbf{R b}$ & Y & $\mathrm{Ba}$ & $\mathrm{Pb}$ & $\mathrm{Sr}$ & $\mathrm{Ga}$ & V & $\mathrm{Nb}$ & $\mathrm{Ag}$ & $\mathrm{Au}$ & $\mathrm{Pt}$ \\
\hline 1 & 9 & 10 & 53 & 242 & 22 & 1086 & 145 & 248 & 342 & 136 & 66 & 32 & 10 & 55 & 15 & 93 \\
\hline 2 & 5 & 16 & 52 & 391 & 152 & 1485 & 333 & 238 & 161 & 82 & 98 & 65 & 20 & 40 & 14 & 66 \\
\hline 3 & 57 & 8 & 108 & 158 & 99 & 21 & 14 & 85 & 169 & 64 & 8 & 73 & 5 & 15 & 10 & 45 \\
\hline 4 & 8 & 6 & 134 & 10 & 20 & 30 & 10 & 212 & u.d & 125 & 19 & 33 & 11 & 60 & 16 & 120 \\
\hline 5 & 7 & 11 & u.d & u.d & 10 & 90 & 99 & 100 & 140 & 89 & 32 & 70 & 19 & 38 & 13 & u.d \\
\hline 6 & 44 & 36 & 740 & 700 & 85 & 250 & 211 & 88 & u.d & 75 & 25 & 60 & 8 & 7 & 22 & u.d \\
\hline Av. & 21.7 & 14.5 & 217.4 & 300 & 64.7 & 493.7 & 135.3 & 161.8 & 203 & 95.2 & 41.3 & 55.5 & 12.2 & 35.8 & 15 & 81 \\
\hline
\end{tabular}

The A/NK vs. A/CNK binary diagram of Maniar and Piccoli (1989) showed that all studied granite samples fall in the peraluminous field (Fig. 5), which have A/CNK molar ratio $>1.0$.

The older granites are rich in $\mathrm{Sr}$ and $\mathrm{Ba}$, while the younger granites are rich in $\mathrm{Rb}$. The wide range of $\mathrm{Sr}$ and $\mathrm{Ba}$ in the older granites (Table 1) indicates fractional crystallization with possible modifications by post magmatic fluid (Bowden, 1982).

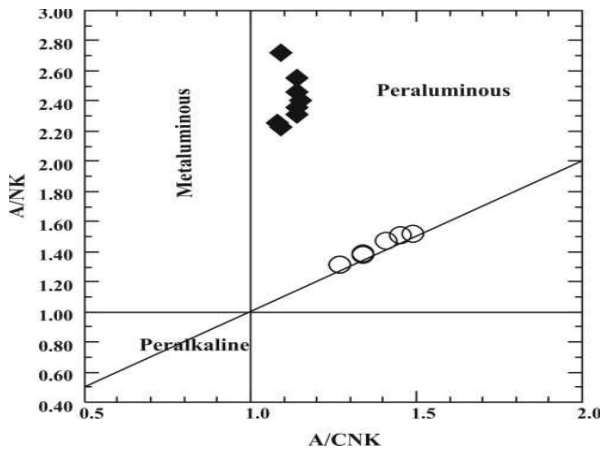

Fig. 5: A/NK vs. A/CNK discrimination binary diagram according to Maniar and Piccoli, 1989. Older granites Younger granites

\section{Tectonic Setting}

$\mathrm{K}_{2} \mathrm{O}$ vs. $\mathrm{Na}_{2} \mathrm{O}$ diagram (Hine et al., 1978) showed that all samples of the El-Dob granites fall in the field of I-type granites (Fig. 6).

On the $\mathrm{Rb}$ vs. $(\mathrm{Y}+\mathrm{Nb})$ and $\mathrm{Y}$ vs. Nb diagrams (Figs. 7a \& b) of Pearce et al, (1984), the older granites were plotted in the field of the volcanic arc granite (VAG) and the younger granites are plotted in within plate granite field (WPG).

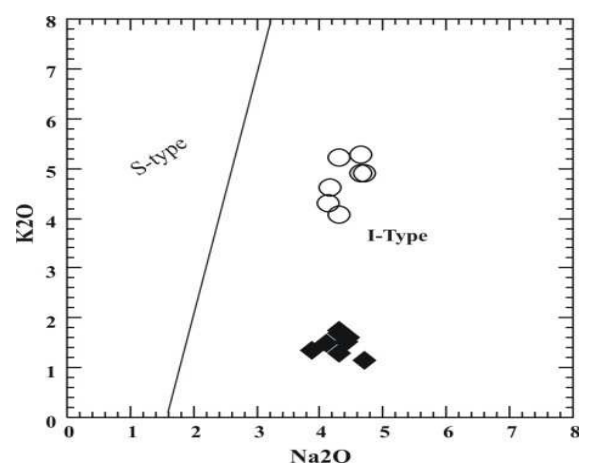

Fig.6: $\mathrm{K} 2 \mathrm{O}$ vs. Na2O binary diagram according to Hine et al., 1978, Older granites 0 Younger granites

Trace elements of six samples of pegmatites are plotted on a geochemical histogram, which showed that highly enrichment in $\mathrm{Cu}$, $\mathrm{Zn}, \mathrm{Y}, \mathrm{Pb}, \mathrm{Ag}, \mathrm{Au} \& \mathrm{Pt}$ (Fig.8). These elements formed minerals as copper, lead, gold and platinum.

\section{SPECTROMETRY}

Gamma-ray spectrometric survey was carried out on the El-Dob granites, using GS-512 spectrometer. The measurements are expressed in ppm for eU \& eTh and in percent for K.

\section{Granites}

The results of statistical analysis of the various radioelements and their ratios of ElDob granites are listed in Table (3).

The radioelement distribution in the younger granites possesses a relatively high average content of $\mathrm{K}$, eU \& eTh. They contain a wide range of these radioactive elements; 

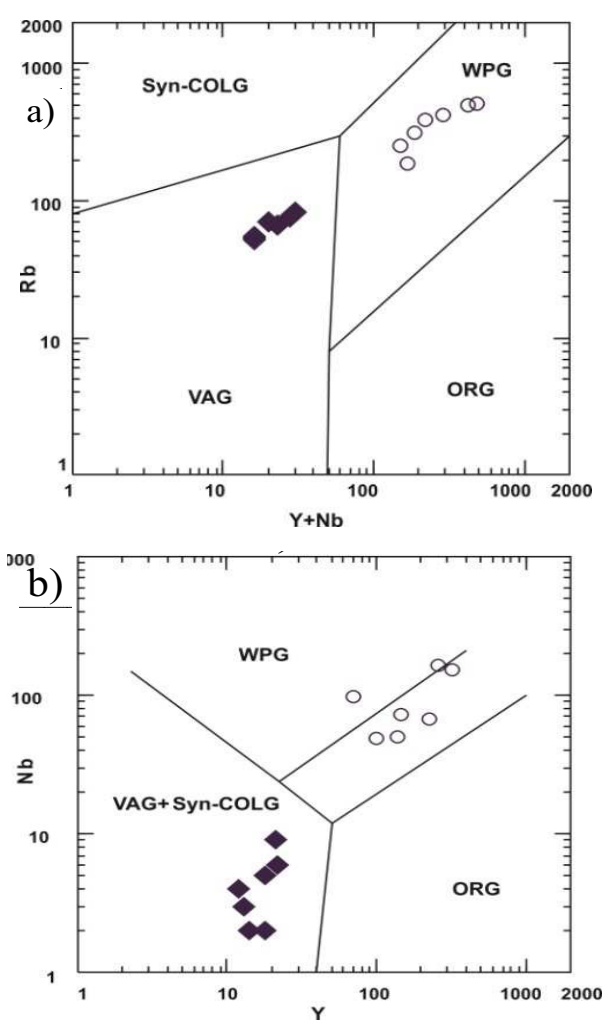

Fig.7 a\&b : Pearce et al. (1984) granitoid tectonic environmental discrimination binary diagrams. a) $\mathrm{Nb}+$ Yvs. Rb and b) $\mathrm{Nb}$ vs. Y. Older granites $\circ$ Younger granites

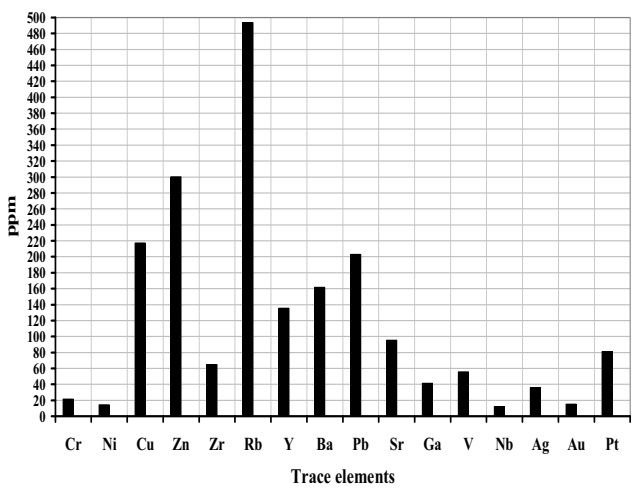

Fig. 8: Histogram showing the distribution of some trace elements in pegmatites and quartz veins, El-Dob granites area

4-7 \% for K, 17-43 ppm for eU, and 50-102 ppm for eTh. Moreover the rocks exhibit wide range variation varies between $0.19-0.49$ for $\mathrm{eU} / \mathrm{eTh}$ ratio, 2-5.1 for eTh/eU ratio. The radioelement distribution in the older granites possesses a moderately average content of $\mathrm{K}$, eU \& eTh. They contain a wide range of these radioactive elements; $1-8 \%$ for $\mathrm{K}, 5-35 \mathrm{ppm}$ for $\mathrm{eU}$, and 17-95 ppm for eTh. Moreover the rocks exhibit wide range variation varies between 1.4-6.6 for eU/eTh ratio, 0.6-4.4 for $\mathrm{eTh} / \mathrm{eU}$ ratio.

The coefficient of variability $(\mathrm{CV} \%)$ is examined to know the normality of El-Dob

Table 3: Statistical analysis of spectrometric data of the younger and older granites of El Dob area

\begin{tabular}{|c|c|c|c|c|c|c|c|}
\hline & $\mathbf{K} \%$ & $\begin{array}{r}\mathbf{e U} \\
(\mathbf{p p m})\end{array}$ & $\begin{array}{r}\text { eTh } \\
(\mathrm{ppm})\end{array}$ & eU/eTh & eTh/eU & $\mathbf{e U} / \mathbf{K}$ & eTh/K \\
\hline \multicolumn{8}{|l|}{ Younger granites $(\mathrm{N}=50)$} \\
\hline Minimum (Min.) & 4 & 17 & 50 & 0.19 & 2 & & \\
\hline Maximum (Max.) & 7 & 43 & 102 & 0.49 & 5.1 & & \\
\hline Range & 4-7 & $17-43$ & 50-102 & $0.19-0.49$ & $2-5.1$ & & \\
\hline Average & 5.3 & 32.5 & 86 & 0.38 & 2.8 & 6.13 & \\
\hline Standard deviation (S.D) & 0.8 & 6.7 & 7.7 & 0.07 & 0.7 & - & - \\
\hline Coefficient of variability (CV\%) & & 206. & 89. & 184 & 25 & & 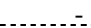 \\
\hline \multicolumn{8}{|l|}{ Older granites $(\mathrm{N}=100)$} \\
\hline Minimum (Min.) & $\mathbf{1}$ & 5 & 17 & 0.15 & 1.4 & 0.63 & 2.1 \\
\hline Maximum (Max.) & 8 & 35 & 95 & 0.72 & 6.6 & 4.4 & 11.9 \\
\hline Range & $1-8$ & $5-35$ & $17-95$ & $0.15-0.7$ & 1.4-6.6 & $0.6-4.4$ & 2.1-11.9 \\
\hline Average & 4.5 & 19.2 & $\mathbf{5 5 . 4}$ & 0.36 & 3.1 & 4.3 & 12.3 \\
\hline Standard deviation (S.D) & 1.1 & 6.3 & 15.6 & 0.11 & 1.04 & - & - \\
\hline Coefficient of variability (CV\%) & & 33. & 28 & 60 & 34 & & \\
\hline \multicolumn{8}{|c|}{ Granites Mountains Wymong in U.S.A (Stuckiess et aI., 1983) } \\
\hline Average & 3.37 & ....54 & 16.78 & 0.21 & .4.73. & 1.05 & 5.00 \\
\hline \multicolumn{8}{|c|}{ Crustal acidic igneous rocks (after IAEA, 1979 and Boyle, 1982) } \\
\hline Average & 4 & ...5 & 18 & 0.25 & 4.00. & 1.13 & .4.5. \\
\hline \multicolumn{8}{|c|}{ Arabian shield in Saudi Ârabia (Stuckless et al., 1983) } \\
\hline Average & 3.95 & 5.02 & 14.42 & 0.35 & 2.86 & 1.27 & 3.65 \\
\hline
\end{tabular}


granites. CV \% is more than $100 \%$ for the younger granites exhibiting abnormal distribution. While CV\% is less than $100 \%$ for the older granites exhibiting normal distribution.

The data of comparison radioelements concentration of El-Dob granites with those of the Granites Mountains Wymong in U. S. A (Stuckless et al., 1983), crustal igneous rocks after IAEA (1979) and Boyle (1982), and Arabian shield in Saudi Arabia (Stuckless et al., 1983) are given in Table (3). From this table several remarks can be noticed:

- The average values and range of $\mathrm{K} \&$ eTh, eU and their ratios of the younger granites and the older granites are higher than those of the Granites Mountains Wymong in U.S.A, crustal igneous rocks and Arabian shield in Saudi Arabia.

- The term uraniferous granites should be applied to El-Dob granites, which contain ( $32.5 \mathrm{ppm}$ eU for the younger granites and $19.2 \mathrm{ppm}$ eU for the older granites) higher than the twice Clarke value (Clarke value for $\mathrm{eU}=4$ and for $\mathrm{eTh}=18-20 \mathrm{ppm}$ ).

- The average value of the eU at El-Dob granites is $32.5 \mathrm{ppm}$ eU for the younger granites and $19.2 \mathrm{ppm}$ eU for the older granites. Gangloff (1970) defined the fertile granites that have uranium content between 15-20 ppm. Hall and Walsh (1969) concluded that the fertile granites are characterized by high $\mathrm{Zr} / \mathrm{Sr}$ ratio more than 1.65. In the older granites and the younger granites, the average content of $\mathrm{Zr} / \mathrm{Sr}$ ratio is of 0.48 and 4.82 respectively, suggesting that the older granites can be considered as infertile granites while, the younger granites are fertile granites.

On Figures (9\&10), the eU/eTh ratio positively increase with the increasing of eU in the younger granites $(r=0.9)$. The eU/eTh ratio positively increases with the increasing of eTh (r=0.3), Fig.11. Charbonneau (1982) stated that if this ratio increase strongly with $\mathrm{eU}$ increase or eTh decrease, post magmatic

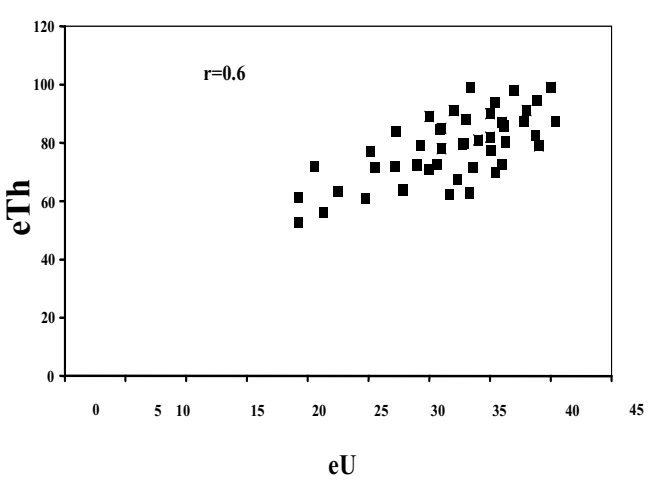

Fig.9: Correlation diagram of eTh vs. eU of the younger granites, El Dob area

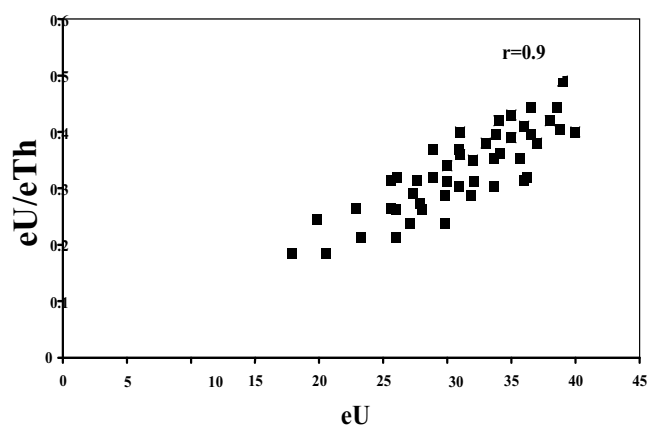

Fig.10: Correlation diagram of eU vs. eU/eTh of the younger granites, El Dob area

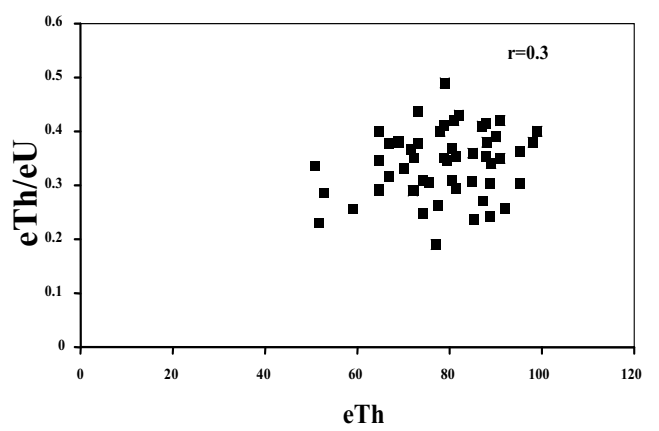

Fig. 11: Correlation diagram of eTh vs. eU/eTh of the younger granites, El Dob area

redistribution of uranium is suggested. If eU/ eTh ratio is inversely correlated with $\mathrm{eTh}$, the radioelement redistribution is, at least in part, governed by magmatic processes. 
For the older granites, binary diagrams of eU vs. eTh, eU vs. eU/eTh \& eTh vs. eU/eTh (Fig. 12-14) declare that there is a strongly positive correlation between $\mathrm{eU}$ and $\mathrm{eTh}$ $(\mathrm{r}=0.6)$ and between $\mathrm{eU}$ and $\mathrm{eU} / \mathrm{eTh}$ ratio $(\mathrm{r}=0.5)$, while there is a weekly negative correlation between eTh and eU/eTh ratio $(r=-$ $0.4)$.

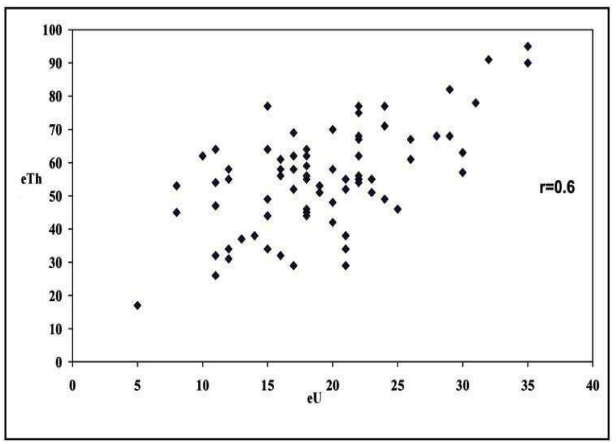

Fig. 12: Correlation diagram of eTh vs. eU of the older granites, El Dob area

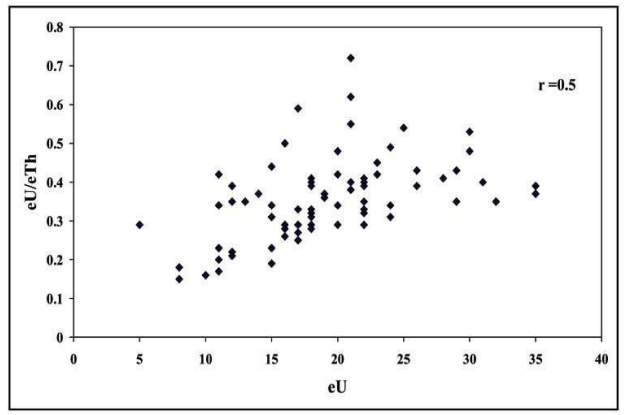

Fig. 13: Correlation diagram of eU vs. eU/eTh of the older granites, El Dob area

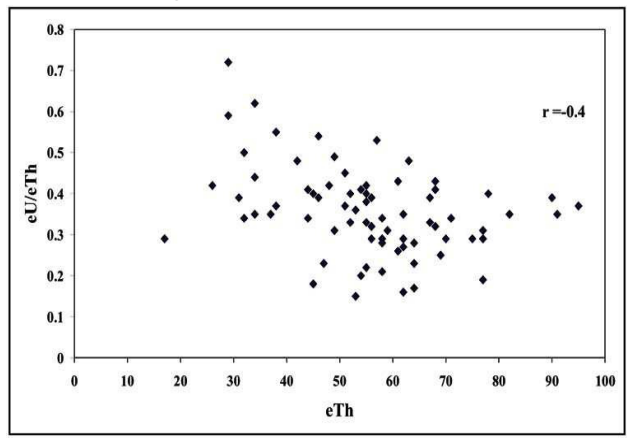

Fig.14: Correlation diagram of eTh vs.eU/eTh of the older granites at El Dob area
However, the trend defined the variation of $\mathrm{eU}$ and eTh with their ratios in the different rock types reflects the amount of remobilization that take place within the different rock units. Also the amount of post magmatic remobilization is indicative of favorability for epigenetic U-mineralization within or near the magmatic pluton (Charbonneau, 1982).

The positive correlation between $\mathrm{eU} \&$ eTh, can be attributed to either the presence of existing uranium bond with thorium in stable accessory minerals or to the lack of percolating oxidizing fluids. The eU vs. eU/eTh showed that there is a strongly positive correlation with eU but not with eTh indicating that post-magmatic redistribution of uranium is suggested. This could be a favorable economic source because uranium may have concentrated into deposits within or near the granites. The eTh vs. eU/eTh showed that a negative correlation indicating that the radioelements distribution is governed by magmatic processes and the thorium was fixed in the early stages of magmatic evaluation (Charbonneau, 1982).

Stuckless, et. al. (1983) suggested that if there is a positive correlation between eU \& eTh indicating that their distribution was controlled by the magmatic process and has not been subjected to any processes of mobilization and redistribution after crystallization.

\section{Pegmatites}

The radiometric analyses of pegmatites (Table 4) show that the eU contents range from 15 to $40 \mathrm{ppm}$ with an average $32.5 \mathrm{ppm}$ and the eTh contents range between 72 and 99 ppm with an average $86 \mathrm{ppm}$. The $\mathrm{K} \%$ ranges between 4.2 and $7 \%$ with an average $5.3 \%$. The eTh/eU ratios range between 2 and 5.1 ppm with an average $2.8 \mathrm{ppm}$. The pegmatites possess relatively high average contents of $\mathrm{K}$, eU \& eTh than the granites. The average and Standard deviation parameters of these radioelements and their ratios are relatively higher. The calculated parameter of Skeweness lies within the limits of -2 to +2 for the $\mathrm{K}, \mathrm{eU}$, eTh, eU/eTh, except eTh/eU which lies outside this 
range indicating some leaching of uranium took place. The calculated parameter of kurtosis lies outside the limits of -2 to +2 for the variables eU, eU/eTh \& eTh/eU which indicates abnormal distributional shape of that data.

Table 4: Statistical analysis of spectrometric data of the pegmatites of El Dob area

\begin{tabular}{|c|c|c|c|c|c|}
\hline \multicolumn{6}{|l|}{ Pegmatites $(\mathrm{N}=15$ ) } \\
\hline & $\mathbf{K} \%$ & $\mathrm{eU}(\mathrm{ppm})$ & $\mathrm{eTh}(\mathrm{ppm})$ & $\mathrm{eU} / \mathrm{eTh}$ & $\mathrm{eTh} / \mathrm{eU}$ \\
\hline Minimum (Min.) & 4.2 & 15 & 72 & 0.19 & 2 \\
\hline Maximum (Max.) & 7 & 40 & 99 & 0.49 & 5.1 \\
\hline Range & 4.5-7 & $15-40$ & $72-99$ & $0.19-0.49$ & $2-5.1$ \\
\hline Average & 5.3 & 32.5 & 86 & 0.38 & 2.8 \\
\hline Standard deviation (S.D) & 0.8 & 6.7 & 7.7 & 0.07 & 0.7 \\
\hline Skew. & 1 & -1.6 & 0.04 & -1.4 & 2.7 \\
\hline Kurt. & 1.5 & 2.7 & -0.5 & 3.3 & 8.8 \\
\hline
\end{tabular}

Figures (15\&16) show that the eU/eTh ratio positively increases with the increase of $\mathrm{eU}$ in pegmatites $(\mathrm{r}=0.9)$. The eU/eTh ratio positively increases with the increase of eTh $(\mathrm{r}=0.3)$, Fig.17. Charbonneau (1982) stated that, if this ratio increases strongly with eU increase or eTh decrease, post magmatic redistribution of uranium is suggested. If eU/ eTh ratio is inversely correlated with eTh, the radioelement redistribution is, at least in part, governed by magmatic processes.

\section{CONCLUSION}

El-Dob area, in the Egyptian Central Eastern Desert, is occupied by small and circular bodies from older and younger granites. The older granitoids are represented by granodiorites and tonalites and they are intruded by the younger gabbros and younger granites with sharp contacts. The younger granites are represented by alkali feldspar granites, which crop out in the central part of the studied area forming Gable El-Dob. The older and younger granites are cut by pegmatite and quartz veins. The mineralogical study of some polished sections of some pegmatite veins show native gold and platinum being recorded for the first time.

Geochemical study revealed that El-Dob granites are peraluminous and I-type granites.

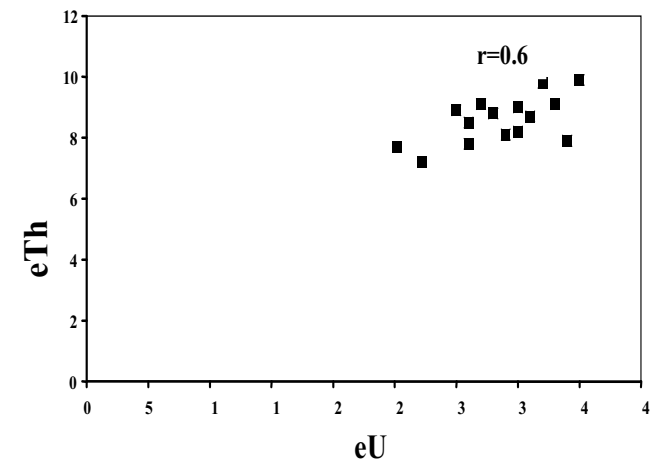

Fig.15: Correlation diagram of eTh vs. eU of the pegmatites, El Dob area.

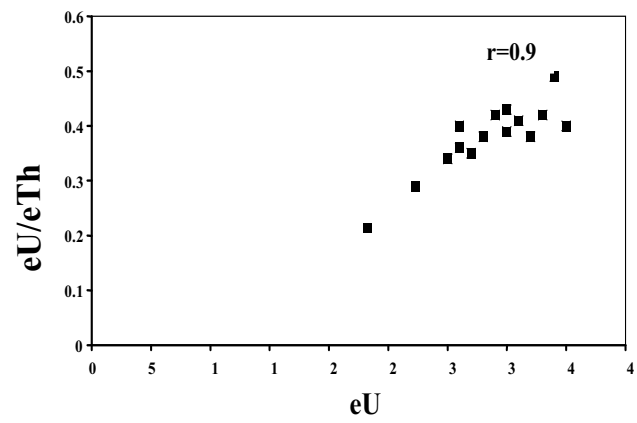

Fig. 16: Correlation diagrams of eU vs. eU/ eTh of the pegmatites, El Dob area.

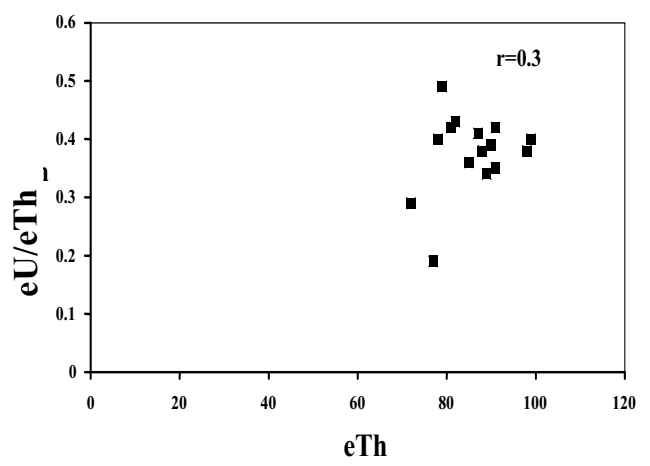

Fig. 17: Correlation diagram of eTh vs.eU/ eTh of the pegmatites, El Dob area.

The the older granites belong to volcanic arc granites (VAG), while alkali feldspar granites belong to within plate granites (WPG). Pegmatite veins possess high contents of important elements as $\mathrm{Zn}, \mathrm{Y}$ and $\mathrm{Cu}$. 
Radiometric study showed that El-Dob granites have relatively high uranium and thorium contents. The average equivalent uranium is $19 \mathrm{ppm}$ for the older granites and 33 ppm for the younger granites, the average eTh is $55 \mathrm{ppm}$ with the average $\mathrm{eTh} / \mathrm{eU}=3.1$ for the older granites and the average eTh is 86 $\mathrm{ppm}$ with the average $\mathrm{eTh} / \mathrm{eU}=2.8$ for the younger granites. These radiometric measurements are higher than the Clark values (Clark et. al., 1966). This means that the El-Dob granite is uraniferous granite. The pegmatites give the highest radioactivity value in the studied area.

\section{Acknowledgements}

The author wishes to express his deep gratitude to Late Prof. Dr. Fathy Ammar, for help in the laboratories and to Prof. Dr. Esmat A. Abu Elhassan and Dr. Mahmoud A. Mohamed for help in the field

\section{REFERENCES}

Abu El Hassan, E. A., 1995. Geology of Gabal Abu Kharief and associated mineralization, Eastern Desert, Egypt. M. Sc. thesis, South Valley Univ., Qena, Egypt, 152p.

Akaad, M. K., and El Ramly, M. F., 1960. Geological history and classification of the basement rocks of Central Eastern Desert. Geol. Surv. Egypt, No. 9, 24 p.

Asran, A. M. H., 2001. Petrography and geochemistry of Sikait gneissose granite complex Eastern Desert, Egypt. Egy. J., 45/2, 883-902.

Bentor, Y. K., 1985. The crustal evolution of the Arabo-Nubian massif with special reference to the Sinai Peninsula. Precambrian Research ,28, 1-74.

Bowden, P., 1982. Magmatic evolution and mineralization in the Nigerian Younger Granite Province. In: Metallization associated with acid magmatism (Evans, A.m. Ed.): London, Wiley, 51-61p.
Boyle, R. W., 1982. Geochemical prospecting for thorium and uranium deposits. Develop. Economic, Geol., 16, 489p.

Charbonneau, B. W., 1982. Radiometric study of three radioactive granitess in the Canadian Shield. In: uranium in granites (Ellotlak, Ontaro, Fort Smith and Fury and Hecla, N.W.T., Y.T Maurice, Ed.,): Geo. Surv., Canada, paper 81-23, 91-99.

Clark, S. P. Jr.;Peterman, J. E., and Heier, K. S., 1966. Abundance of U, Th and K. In: Handbook of physical constants (Clark, S. P. Jr.,Ed.): Mem. Geol. Soc. Am. , 97, 587p.

De La Roche, H.; Leterrier, J.; Grandclaude, P., and Marchal, M., 1980. A classification of volcanic and plutonic rocks using R1-R2 diagram and major element analyses; its relationships with current nomenclature. Chem. Geol., 29,183-210.

El Shazly, E. M., 1957. Control of tertiary ore deposition in Egypt. Chronique des mines of outer mer et de la Recherche miniere.

El Tahir, M. A., 1978. Relation between geology and radioactivity of some basement rocks to the north of Qena-Safaga asphaltic road, Eastern Desert Egypt, M.Sc. thesis, Al Azhar Univ., Cairo, Egypt, 101p.

Gangloff, A., 1970. Notes somaires la geologie des principaux districts uranoferes studies par la CEA. In : Uranium exploration geology, I.A.E.A., Vienna,77-105 (IAEA - 391 $-16)$.

Hall, M. A., and Walsh, J. N., 1969 Rapid method for the determination of fluorine in silicate rocks and minerals. Ann. Chem. Acta., 45, $341-342$.

Hassan, M. A.; Aly, M. M.; and Eid, A. S., 1984. Petrographical and geochemical studies on the radioactive psammitic gneiss of Wadi Abu Rusheid, Eastern Desert, Ann. Geol. Surv. Egypt, V. XIII, 143-155.

Hassan, M.A., and Hashad, A.H., 1990. Precam- 
brian of Egypt. In: the Geology of Egypt (Said, R.,Ed.): Balkema, Rotterdam, 201-245.

Hine, R. H.; Williams, I. S.; Chappell, B. W., and White, A.J.R., 1978. Geochemical contents between I \& S-type granitiods of the Kosciusko Batholith. J. Geol. Soc. Aust., 25, 219234.

International Atomic Energy Ageney (IAEA), 1979. Gamma ray surveys in uranium exploration, Technical Report Series, Vienna, paper no.186, 90 .

Maniar, P. D., and Piccoli, P.M., 1989. Tectonic discrimination of granitoids. Geol. Soc. Am. Bull., 101, 635-643.

Middlemost, E.A.K., 1985. Magmas and magmatic rocks. An introduction to igneous petrology. Longmen Group Ltd, Essex, 266p.

Pearce, J. A.; Harris, N. B. W., and Tindle, A. G., 1984. Trace element discrimination diagrams for the tectonic interpretation of granitic rocks. J. Petro. ,25, 958-983.

Sabet, A. H.; El Gaby, S., and Zalata, A. A., 1972b. Geology of the basement rocks in the northern parts of El Shayib and Safaga sheets, Eastern Desert. Ann. Geol. Surv. Egypt, Cairo, II, $111-128$.

Stern, R.J.; Gottfried, D., and Hedge, C.E., 1984. Late Pre-cambrian rifting and crustal evolution in the Northeastern Desert of Egypt. Geol., 12, 168-172.

Stuckless, J. S.; Nokomo, I.T.; Wenner, D. B., and Vantrump, G., 1983. Geochemistry and uranium favorability of the post-orogenic granitess of the northwestern Arabian Shield, Kingdom of Saudi Arabia. Bull, Fac., Earth Sci., King Abdulaziz Univ.,6, 195-209.

Takla, M. A., and Nowier, A, M., 1980. Mineralogy and mineral chemistry of the ultramafic mass of El- Rubshi, E. D., Egypt. Neves Jahrb. Min. Abh., 140/1, 17-28.

Vail, J.R., 1986. Tectonic control of dykes and related irruptive rocks in eastern Africa. In: African Magmatism and Tectonics (Clifford, T.N., Gass, I.G.,Ed.): Hafner, Darien, Connecticut, 337-354.

$$
\begin{aligned}
& \text { جرانيتات منطقة جبل الاب والبجماتيت المرتبط بها، وسط الصحر اءع الثرقية ، مصر الإبة } \\
& \text { الجيوكيمياء والطيفية الاشعاية الئية } \\
& \text { فر اج محمد خليل } \\
& \text { تقع منطقة جبل الدب في وسط الصحر اء الثرقية لمصر. تحوي صخور الحمّي الأفريقي المتأخر علي هيئة }
\end{aligned}
$$

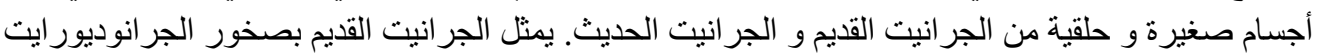

$$
\begin{aligned}
& \text { و التونالايت وهي مقطوعة بصخور الجابرو الحديث و الجرانيت الحديث. أما صخور الجرانيت الحديث ممثلة } \\
& \text { بصخور الجر انيت ذو الفلسبار القلوي والذي يظهر في وسط منطقة الدر اسة مكونا جبل الدب. وكلا من الجر انيتات } \\
& \text { القديمة والحديثة مقطوعة بعروق البجماتيت و الكوارتز. جر انيت الدب القلوي فوق الوميني، ومجماتي النشأة }
\end{aligned}
$$

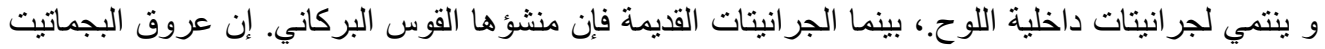

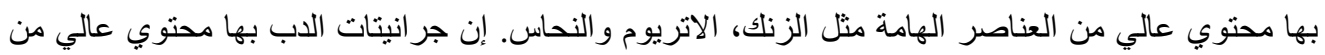

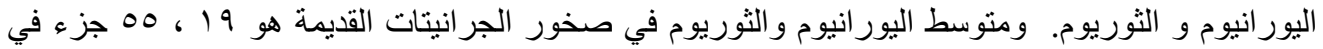

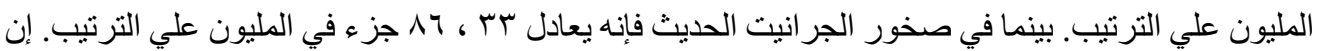

$$
\begin{aligned}
& \text { هذه القياسات الر اديومترية أعلي من قيمة كلارك بما بدل علي أن جر انيت جبل الدب ولب و اعد في اليور انيوم. في حين }
\end{aligned}
$$

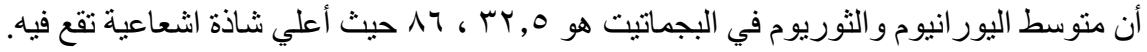

